\title{
A WESTERN OPINION ${ }^{1}$
}

\author{
By R. G. McKEE ${ }^{2}$
}

Mr. President and Fellow members of C.I.F. I have been asked to give a Westerner's reaction to what I have seen.

My first reaction is one of admiration and gratitude for a well organized and interesting convention, conducted in a spirit of forestry friendship.

As $I$ have been involved in organizing a three-day convention this December for Western forestry, I know something of the work involved so am pleased at the chance to publicly thank all of you in the Host section.

On Monday you heard from a middle-aged mensurationist so today you are hearing from a tired old man-I mean a Retired Deputy Minister. So if my ramblings are disjointed and garrulous you will have to blame it on old age. If, in my zeal to "beat the drum" I inadvertently step on some toes, I apologize in advance for the impulsive disposition bequeathed to me by my fighting Irish ancestors.

In the first place it was interesting to note that so many of you are engaged in the production end of Forestry and are able to show top management that Foresters can be doers as well as thinkers. I trust that our educators and particularly Professor Garret gets the message that logging engineering is a fundamental part of a Professional Forester's training.

I would venture the prediction that if my own Alma Mater continues to give a chance of easy options, a lot of you may be approached by desperate Western firms once our gigantic small wood economy gets rolling.

I was interested in your sample experiments in Forestry and gained the impression we have seen most of the forestry being practised at the Lakehead.

Out West we have a theory that the best acres on which to practise Forestry are those closest to the plant, but after walking for miles last Sunday looking for partridge some 20 miles north of here, I looked in vain not only for birds but for stands of thriving conifers.

Similarly, the two drives we took on tour confirmed my impression that you have some 800,000 acres of weed forests behind these pulp mills, and at say $\$ 50$ per acre to reclaim them, you are now tilting at windmills with an ARDA Project in this vicinity.

Last summer I had a visit from a leader of the pulp workers union in Quebec who complained that at the bargaining table they were always told "No, we can't afford to raise your pay very much because each year we must go farther and farther back for our timber."

Now after our wonderful tours, I can believe him.

In searching for the reason, I was loaned a very revealing little brochure put out by the Ontario Department of Lands \& Forests called "Authorized Annual Cut vs. Actual Annual Cut", published in March, 1963.

\footnotetext{
${ }^{1}$ Presented following the field trips of the 1965 Annual Meeting of the C.I.F.

- Former Deputy Minister of Forests, B.C., now Chairman, B.C. Purchasing Commission, Victoria, B.C.
} 
This publication shows that at that time most companies in Ontario could double or treble the size of their plants and still remain within the cutting budget in conifers alone. As long as this situation remains, how can you get hard-boiled management interested in expensive forestry?

Jack Nicholson told me that he did his best to persuade some eastern Canadian firms to put up kraft mills to give your forests a better deal but in some cases he received a flat "not interested". However, times are changing and I am pleased to learn you have one such plant soon to come into production, so that the Great Lakes Paper Company's requirements will advance from 500 to 880 thousand cords annually. Then you Foresters can keep your logging costs down and the Company will be practising Forestry provided the Ontario Forest Service can get enough funds under the iniquitous Bill No. 56.

One other impression I must convey is my great disappointment at Forest Minister Sauvé's speech. I am sorry that Resolution No. 2 was not approved even in its revised form.

I must confess it gives me some satisfaction to read you the following paragraph which the Vancouver Island section had in the original resolution. "And Whereas in his letter of February 20th, 1964, the Prime Minister stated 'that the change in status of the Forestry Department to that of Forestry and Rural Development does not mean that forestry will take a lesser place in Government interest.'

"Which statement is contradicted by the fact that $64 \%$ of the Forestry Department's 1965-66 budget of 59 million dollars is being spent on ARDA or other agricultural projects, while at the same time there is an entire agricultural department in Ottawa with a budget of 122 million dollars."

Now I have no quarrel with the present research expenditures of $\mathrm{Mr}$. Sauvé's department and I have nothing but admiration for our fellow foresters who are devoting their lives to work that would drive me around the bend, but surely, Mr. Sauvé, enough is enough.

It doesn't take a nickel's worth of research out west to know that two of our northern district foresters have an area between them to administer three times larger than all the Maritimes put together.

That we shall need thousands of miles of access road to get at distant fires. What is the use of finding more bug damaged timber when we can't get at it to salvage same?

In British Columbia we haven't scratched the surface of intensive and expensive forest management, so please let's put first things first and quit kidding the public into thinking that all these vital problems can be solved by more elaborate research plants which we can well do without at this time. 